glands are due the changes so frequently occurring in the colour of the hair and of the other cutaneous organs. Here also the pathologic action passes step by step from its most aggravated forms to its lightest phases, merging at last in simple physiological functions. The dark races, notably the Negroes, have had their origin in malarious regions, whose influence generates in serious cases a deposit of pigment or melanosis, occasionally manifested under the form of black tumours. The observations made by Prof. Klebs and others in the Pontine Marshes and Roman Campagna, show that the malaria is caused by a certain bacillus developed in the soil of those districts. Hence it may in this case be admitted that pathological actions of a comparatively mild form may exercise a modifying influence on the structural development of man. They should perhaps even be regarded as the true causes of the evolution of human types.

However crude and even unsatisfactory these views, they will doubtless serve a useful purpose by directing attention to a hitherto neglected field of research. They at all events reopen the whole question of the origin of human varieties, a question which cannot be considered as closed until monogenists and polygenists have reconciled their differences. The author's theory seems so far to support the monogenist school, inasmuch as it tends to account for present diversity by natural causes, without the necessity of having recourse to several independent centres of human evolution. The weak point of the theory seems to be that these natural causes are themselves confessedly of an exceptional character. It requires us to believe that the human varieties were evolved under morbid, that is, abnormal, conditions. Before that conclusion can be accepted, it will be necessary to show that the normal conditions of climate, diet, and so forth, were inadequate for the purpose. Unless this is done, the normal will probably continue to be regarded as, cateris paribus, more efficacious than the abnormal causes.

A. H. KEANE

\section{THE GERMAN EXPEDITION TO SOUTH GEORGIA}

THE following is an abstract of the report of the German Meteorological Expedition which was despatched under the international scheme to South Georgia Island, in lat. $54^{\circ} \mathrm{S}$. and long. $37^{\circ} \mathrm{W}$.

The Expedition, which was chosen by a Commission appointed by the German Government, consisted of the following members:-Dr. C. Schrader, chief, observer of the Hamburg Observatory; Dr. P. Vogel, 'sub-chief, mathematical instructor in Munich; Dr. C. von der Steinen, physician and zoologist, physician at the Charite Hospital in Berlin; Dr. H. Will, botanist, of the Forest Academy; Dr. O. Claus, mathematician; Herren E. Mosthoff, engineer, and A. Zschau, assistant ; and a few sailors.

The object of the Expedition was to effect meteorological and magnetic observations, and to study the physical condition and the flora and fauna of the island, as well, as far as permissible, to observe the transit of Venus on December 6, 1882 .

The Expedition arrived at Monte Video on July 4, 1882 , by one of the Hamburg liners, and left that place on the $23 \mathrm{rd}$ on board the German man-of-war Mollke, after having adjusted their instruments and obtained a few domestic animals.

After twenty days' sailing the island was sighted; on August 20 the ship reached Royal Bay on the east coast. On the shore preparations were at once begun for removing the metre-deep snow, and erecting the dwelling house, i $\times 8$ metres, two smaller houses for the magnetic observations, an astronomical observatory, and a small tower. A house was also built for the cattle.

All the scientific members, with the exception of those on the watch for reading the meteorological and magnetic instruments, met daily in the work-room from 9 a.m. to 12 noon, and from 2 to 6 p.m., to execute the scientific labours.

The instruments were read every hour, while the watches of the twenty-four hours were divided so that two members were on duty, the one from 3 to 9 a.m., and from 3 to 9 p.m., and the other from 9 a.m. to 3 p.m., and again from 9 p.m. to 3 a.m., and in this manner each member had two days' watch in the week. On the Ist and I 5 th of every month magnetic observations were effected every fifth minute, and for one hour on these days every twentieth second. But the labour was not found to be at all too heavy.

The lowest temperature registered was $-14^{\circ} \mathrm{C}$., and the highest on one single occasion $18^{\circ} \mathrm{C}$., but the thermometer varied generally in all seasons between $-5^{\circ}$ and $+7^{\circ} \mathrm{C}$., so that the difference between winter and summer consisted chiefly in the length of the days. Once during the winter-in August-the phenomenon occurred of the thermometer during, with a heavy westerly gale, to $14^{\circ} \mathrm{C}$. The westerly and partly south-westerly winds were, during the winter, the warmest, which was ascribed to the circumstance that these passed over mountains some 2000 metres in height protecting the station on one side, which made them "Föhn-like."

The barometer readings varied between 715 and $770 \mathrm{~mm}$. The lowest readings were never attended by violent storms ; these occurred always quite unexpectedly when the glass stood at "fair." The force of the storms, which generally lasted twelve to twenty-four hours, and reaching the island seven to eight times a month, was calculated by a splendid Racknagel anemometer. The tide was carefully measured by ebb and flood gauges.

Falls of rain or snow were very rare during the year, and the plateau surrounding Royal Bay was already, in August, free from snow, and became first in April, when the ground was frozen, covered with snow. It snowed, however, several times in the middle of the summer, as, for instance, at Christmas.

The most frequent winds were those from west and south-west; the northerly ones always brought fog. In the summer the weather was nearly always thick and hazy, which greatly impeded excursions. Such were, nevertheless, undertaken several times, and the highest peaks of the arms-about $700 \mathrm{~m}$. - of the chain of mountains running through the island were ascended. The central mountains range from $2000 \mathrm{~m}$. to $3000 \mathrm{~m}$. The climbing of the slate rocks was very difficult and fatiguing, and in spite of every effort the greatest distance covered was only about a German geographical mile, and the task of exploring the island was impossible of accomplishment, as the glaciers could not be passed by the small force at disposal. The mountains fell of ten abruptly into the sea, and the highest tops were about $15 \mathrm{~km}$. from the station. The peaks of the above-mentioned arms were free from snow in the summer, and then covered with various kinds of moss.

The only rock found was clay-slate, in some places interspersed with varieties of quartz. Even the blocks carried down by the glaciers from the central part of the island - which was not reached-were of the same nature. No metals were found, but the slate rock contained a little iron; the quantity was, however, so small that it hardly affected the needle.

No land mammalia were found on the island, and of maritime mammals only the sea-elephant (Phoca proboscidea) and the sea-leopard, the latter in very small numbers. They did not breed in the bay. Of birds there were several. Two kinds of penguins (König and Esel) visited the island in great numbers, making their nests there, which always faced the sun. The eggs were very delicious. During the pairing-season large quantities of Procellaria gigantea came to the island, whose eggs were 
also very good. Procellaria capensis-the Cape Pigeon -was a summer visitor only, but was found in great numbers, hatching in little holes under the turf. This bird was so persecuted by a kind of gull that it only left its nest after dark. Another specimen of Procellaria also visited the island in the summer. It was named "Equinoxalis." There was only one kind of duck, and this became very scarce through shooting. The number of cormorants was very small, while the albitross (Diomedea) remained during the summer only, when it made its nest hanging from the rociss. They had magnificent brown feathers. Of the white albutross only two specimens were seen, but the white Dominican gull was comnon. Some few of the Chionis alba-the Antarctic Pigeonwhich were eaten, remained during the whole year, as well as a singing-bird of the size of a lark.

The insects found were few, viz. only a specie; of land-beetle without win resembling the common German Lauf-käfer, and a waterbeetle of the same size. A kind of red spider was caught unter big stones. Of lower maritime invertebrates a good collection was made, which has, however, not yet been classified. The greatest part of this was, however, obtained when the tide was out and no boat was necessary, and the dredging was unsatisfa tory.

In the summer two species of fish were caught in calm weather, varying from 5 to $20 \mathrm{~cm}$. in length. But none were caught during the winter. The Expedition collected only about forty species of land and water plants, among the former of which were several varieties of the Tussack grass, two kinds of moss, two kinds of fern, and a little shrub with leaves and red blossoms. The grass was ravenously consumed by the cattle and the goats, but the sheep preferred this little shrub. Dr. Will is under the impression that he has discovered some new varieties.

The transit of Venus was seen in perfect weather, although a severe storm raged at the time. The ingress and egress were clearly observed, as well as the progress over the sun's disk, but no photographs were taken, as the Expedition was not furnished with suitable apparatus.

The island posseised, in spite of its desolateness, a beautiful Alpine nature, the tranquillity of which was only broken by the constant thunder of avalanches. The dwelling-house was comfortsble, although it would have been more so if each member had had a separate rosm instead of its being shared with another. The provisions furnished to the Expedition left, however, much to be desired. The tinned Australian meat was tasteless, and the vegetables bal. The milk (in tins) only lasted six months, while the salt meat and fish, although good, were not sufficient. No fresh potatoss were furnished, the claret was bad, and the beer was soon consumed. The cook did wonfers, however, in the way of culinary achievements. There was no case of scurvy, neither any serious case of illness. Some experiments were made during the sum ner to cultivate beans, peis, and potatoes, but they failed, as the shoots were destroyed by cold as soon as above the ground.

The Expedition left the island on Septem'ser 5, I883, in the German corvette Marie, but all the house; were left intact.

Four of the members of the Expedition returned ho:ne, but Dr. Vogel spent a cousle of months in travelling in the Argentine Republic, while Messrs. Will and Claus are negotiating with the Argentine Govern nent about taking the command of an expedition for explorin $x$ the course of the River Pilco nayo, in which the celebrated explorer Creveaux lost his life. Should their negotiations fail, these gentlemen intend to undertake a journey to the Brazilian province of $M$ atto Grosso, and thence make an exploration of Central Bolivia (Santa Cruz de la Sierra), and erentually follow the watercourses of Mamore ant Madeira i.ato the Amazon River, an 1 then the latter to its mouth.

\section{ALLEN THOMSON}

BORN in Edinburgh, April 2, I809, Allen Thomson had nearly completed his severty-fifth year when he died on the evening of Friday last, March 2I. He was the son of John Thomson, a distinguished physician, who was the first occupant of the Chairs of Military Surgery and of Pathology in the University of Edinburgh, and it is remarkable that both chairs were founded on his own recommendation. Allen Thomson graduated as M.D. at the University of Edinburgh in 1830 , and in 183I he became a Fellow of the Royal College of Surgeons of Edinburgh. Soon after graduation he became an extra-mural Lecturer on Anatomy along with William Sharpey. The atmosphere of the Edinburgh school at this time was highly charged. A number of men, afterwards famous, were either students or extra-mural teachers. It is sufficient to mention the names of John Reid, John Goodsir, Martin Barry, Edward Forbes, William B. Carpenter, and John Hughes Bennett. All of these became distinguished in biological science, and amongst them in these diys there was the clash of intellect and the rivalry of a noble ambition. None of these remain except Dr. Carpenter, who must feel that the death of his friend Allen Thomson is the severance of another link connectung him with what was undoubtedly a brilliant epoch in the history of the Edinburgh medical school.

Dr. Thomson filled the Chair of Anatomy in Marischal College, Aberdeen, from 1839 to I84I, when he was appointed to the Chair of Physiology in Edinburgh. He held this office for six years, whe a he was transplanted to the Anatomical Chair in the University of Glasgow, which he occupied till 1877 . Since then he has resided in London. Of his scientific honours it is unnecessary to say more than that they came without stint; but probably the crowaing honour of this kind was when be filled the Presid intial Chair of the British Association at the Plymouth meeting in 1877.

Allen Thomson had a double career to a greater extent than most scientific men. $\mathrm{He}$ was not merely, by his own researches and by his well-known exhaustless stores of knowledge, on $\geqslant$ of the leading living authorities in the department of embryology, but he was an eminent public man, interested and influential in many matters of social and scientific politics. In Glasgow for many years he rendered the city and the University invaluable service. By his energy and tact he contributed more than probably any other man to the great work of building the new University on Gilmore Hill.

But with all his public work he was a busy man in his own department. His early work brought him reputation as an embryologist, and he kept it up by many i nportant papers in the same department of science. In addition he wrote on physiological optics, especially on the mechanism of accom notation, and on the sensibility of the skin. His writings were not characterised so much by brilliant originality as by facility of interpretation of the writings of others, and by a running conmeatary of his owa, showing that he had repeated the observations he was nurrating with the effect of adding a few facts here and cutting out what he believed to be erroneous there. His method of thought and literary style were both severe. He was always sceptical until convinced, and he strove to get from himself and from others accuracy in detail. Hence he was inclined to be severe on new discoveries or theories, and whilst re idy to listen was rather apt to quench the enthusiasm of a tyro by a douche of cold praise. But still his mind was open and reseptive, and in $n$ t a few instances he changed his opinions unter pressure of argument, which canaot be always asserted even of scientific men. Dr. Thomson always had a greater interest in embryological science tian in any other department of biology, and none hailed with more delight the rise of the modern British school, nor 